\title{
Cluster detection of HIV infection for clients of female sex workers in selected districts of Tamil Nadu, South India
}

\author{
Vasna Joshua ${ }^{1 *}$, K Bhoopathi $^{1}$, Ramesh S Paranjape ${ }^{2}$, Thilakavathi Subramanian ${ }^{1}$, S Mehendale ${ }^{1}$ \\ From 2nd International Science Symposium on HIV and Infectious Diseases (HIV SCIENCE 2014) \\ Chennai, India. 30 January - 1 February 2014
}

\section{Background}

The spread of the HIV epidemic is diverse. The risk behaviors of the HIV infected individuals are not distributed uniformly across the population, but tend to cluster in specific high risk groups. The objective of the study is to explore whether HIV infected individuals are geographically clustered using Kulldorff space time scan statistics.

\section{Methods}

A large cross sectional Integrated Behavioral and Biological Assessment (IBBA) survey for clients of female sex workers (FSWs) in the three districts (Chennai, Madurai and Salem) of Tamil Nadu, South India was carried out by India AIDS initiative, the Avahan project. The survey collected information from 1217 clients of female sex workers between June and September 2009. The data set was geocoded using Google Earth, Kulldorff Space time Scan Statistics was used for detection of clusters among the clients of FSWs.

\section{Results}

Kulldorff Space time Scan Statistics identified a most significant cluster at the location of latitude $13.123^{\circ} \mathrm{N}$ and longitude of $80.293^{\circ} \mathrm{E}$ with the spatial dependency of $8.39 \mathrm{~km}$ radius.

\section{Conclusions}

The study shows initial evidence of geographical clustering of HIV cases. However this observation needs to be substantiated by undertaking similar studies in other states of India. Also, it is important to critically explore biological and behavioral reasoning for such an occurrence. This

\footnotetext{
* Correspondence: vasnajoshua@yahoo.com

${ }^{1}$ National Institute of Epidemiology, Ayapakkam, Chennai, India

Full list of author information is available at the end of the article
}

would also pave a way to build models incorporating clustering effect in the model and might help to design precise and more focused intervention approaches

\section{Authors' details}

${ }^{1}$ National Institute of Epidemiology, Ayapakkam, Chennai, India. ${ }^{2}$ National AIDS Research Institute, Pune, India.

Published: 27 May 2014

\section{doi:10.1186/1471-2334-14-S3-027}

Cite this article as: Joshua et al:: Cluster detection of HIV infection for clients of female sex workers in selected districts of Tamil Nadu, South India. BMC Infectious Diseases 2014 14(Suppl 3):O27.
Submit your next manuscript to BioMed Central and take full advantage of:

- Convenient online submission

- Thorough peer review

- No space constraints or color figure charges

- Immediate publication on acceptance

- Inclusion in PubMed, CAS, Scopus and Google Scholar

- Research which is freely available for redistribution
() Biomed Central 